慶應義塾大学学術情報リポジトリ

Keio Associated Repository of Academic resouces

\begin{tabular}{|c|c|}
\hline Title & Isolation and structures of new peptide antibiotics, cirratiomycin $\mathrm{A}$ and $\mathrm{B}$ \\
\hline \multicolumn{2}{|l|}{ Sub Title } \\
\hline Author & $\begin{array}{l}\text { 城座, 映明(Shiroza, Teruaki) } \\
\text { 海老沢, 直之( Ebisawa, Naoyuki) } \\
\text { コジマ, アツコ( Kojima, Atsuko) } \\
\text { 降旗, 桂子( Furihata, Keiko) } \\
\text { 島津, 昭( Shimazu, Akira) } \\
\text { 遠藤, 豊成( Endo, Toyoshige) } \\
\text { 瀬戸，治男( Seto, Haruo) } \\
\text { 大岳, 望( Otake, Noboru) }\end{array}$ \\
\hline Publisher & 共立薬科大学 \\
\hline Publication year & 1982 \\
\hline Jtitle & $\begin{array}{l}\text { 共立薬科大学研究年報 (The annual report of the Kyoritsu College of } \\
\text { Pharmacy). No.27 (1982. ) ,p.58- } 60\end{array}$ \\
\hline \multicolumn{2}{|l|}{ JaLC DOI } \\
\hline \multicolumn{2}{|l|}{ Abstract } \\
\hline Notes & 抄録 \\
\hline Genre & Technical Report \\
\hline URL & $\begin{array}{l}\text { https://koara.lib.keio.ac.jp/xoonips/modules/xoonips/detail.php?koara_id=AN00062898-0000002 } \\
\text { 7-0058 }\end{array}$ \\
\hline
\end{tabular}

慶應義塾大学学術情報リポジトリ(KOARA)に掲載されているコンテンツの著作権は、それぞれの著作者、学会または出版社/発行者に帰属し、その権利は著作権法によって 保護されています。引用にあたっては、著作権法を遵守してご利用ください。

The copyrights of content available on the KeiO Associated Repository of Academic resources (KOARA) belong to the respective authors, academic societies, or publishers/issuers, and these rights are protected by the Japanese Copyright Act. When quoting the content, please follow the Japanese copyright act. 


\title{
Isolation and Structures of New Peptide Antibiotics, Cirratiomycin $\mathbf{A}$ and $\mathrm{B}^{\dagger}$
}

\author{
Teruaki Shiroza*, Naoyuki Ebisawa,* Atsuko Kojima, \\ Keiko Furihata*, Akira Shimazu*, Toyoshige Endō, \\ Haruo SETo* and Noboru ŌTAKE*
}

In the course of screening for antifolic metabolites using Lactobacillus casei as a test organism growing on a synthetic medium with a limiting amount of folic acid, two peptide antibiotic cirratiomycin A (1) and B (2) have been isolated from the culture filtrate of Streptomyces cirratus 248.-Sq 2 In this paper, we describe the isolation and structural elucidation of these antibiotics.

Streptomyces cirratus 248-Sq 2 was cultivated in a medium consisting of $2.0 \%$ soybean meal, $2.5 \%$ dextrin, $0.5 \% \mathrm{NaCl}$ and $0.4 \% \mathrm{CaCO}_{3}$ in jar fermenters at $27^{\circ} \mathrm{C}$ for $72 \mathrm{hr}$. The filtered broth (50 liters) was treated with activated carbon ( $1 \%$ ) and the carbon cake was eluted with $70 \%$ aqueous acetone $(\mathrm{pH} 3.0)$. After concentration, the eluate was passed through a column of Dowex $50 \mathrm{~W}-\mathrm{X} 2\left(\mathrm{H}^{+}\right.$form) and the column was developed with $5 \%$ pyridine. The active principles were separated by a series of column chromatographies using Dowex 50 W-X 2 (0.5 м pyridine-AcOH buffer, $\mathrm{pH}$ 6.4). Sephadex G-25 (partition, $n$-BuOH-AcOH-water $4: 1: 2$ )and Toyopearl HW $40 \mathrm{~F}$ to afford $50 \mathrm{mg}$ of 1 and $30 \mathrm{mg}$ of 2 in pure form.

1 , an amorphous white powder $\left(\mathrm{pKa}^{\prime} 3.4,6.7,8.8\right)$, shows positive ninhydrin reaction (pale purple), $\lambda_{\max }^{\mathrm{H} r \mathrm{O}} 225 \mathrm{~nm}(\varepsilon 14400)$ and $u_{\max }^{\mathrm{KBr}} 1650 \mathrm{~cm}^{-1}$ suggesting the presence of peptide bonds. In the FD mass spectrum, two ion peaks were found at $m / z 728(\mathrm{M}+\mathrm{H})^{+}$and 750 $(\mathrm{M}+\mathrm{Na})^{+}$indicating the molecular weight of 727 for 1 . Based on the elemental analysis and ${ }^{13} \mathrm{C}-\mathrm{NMR}$ spectrum which revealed seven $\mathrm{CO}$, one $\mathrm{C}=\mathrm{C}$ and one $\mathrm{C}=\mathrm{N}$ bonds, the molecular formula of monohydrochloride of 1 was deduced to be $\mathrm{C}_{31} \mathrm{H}_{53} \mathrm{~N}_{9} \mathrm{O}_{11} \cdot \mathrm{HCl}$ (calcd. $\mathrm{C} 48.72, \mathrm{H} 7.07, \mathrm{~N} 16.50, \mathrm{O} 23.05, \mathrm{Cl} 4.65$, obs. C 48.39, H 7.20, N 16.98, O 24.11, Cl 4.16\%. 10-degree of unsaturation), indicating the presence of a ring structure in 1 .

$1\left(10 \mathrm{mg}\right.$ ) was hydrolyzed with $6 \mathrm{~N} \mathrm{HCl}$ at $120^{\circ} \mathrm{C}$ for $16 \mathrm{hr}$ in a sealed tube. After removal of $\mathrm{HCl}$ in vacuo, the residue was charged on a column of Dowex $50 \mathrm{~W}-\mathrm{X} 2$ (pyridine-AcOH buffer, $\mathrm{pH}$ 6.4) to separate into a neutral amino acid mixture and one basic amino acid which was identified as a diastereomeric mixture of $\alpha, \beta$-diaminobutyric acid (abbreviated as Dab) by ${ }^{1} \mathrm{H}-\mathrm{NMR} .{ }^{1}$ ) The neutral amino acid fraction was successfully separated into four amino acids by a Sephadex G-25 partition column chromatography ( $n$ - $\mathrm{BuOH}-\mathrm{AcOH}$-water $4: 1: 2$ ). The first three were identified as L-Leu, L-Ala, L-Ser and the last unknown amino acid was determined as hydroxymethylserine (HMSer) by

$\dagger$ Agr. Biol. Chem. 46 (3), 865 7 (1982) 飞発表.

* Institute of Applied Microbiology. The University of Tokyo. 
direct comparison ( ${ }^{1} \mathrm{H}-\mathrm{NMR}$, amino acid analysis) with an authentic sample. ${ }^{2)}$ The amino acid analysis and ${ }^{1} \mathrm{H}-\mathrm{NMR}$ spectrum of 1 indicated the equimolar composition of these five amino acids, while its ${ }^{13} \mathrm{C}-\mathrm{NMR}$ spectrum suggested further existence of two acid-labile amino acids, temporarily designated as $\mathrm{X}$ and $\mathrm{Y}$. The $400 \mathrm{MHz}{ }^{1} \mathrm{H}-\mathrm{NMR}$ spectrum of 1 (DMSO- $d_{6}$ ) afforded four doublet $\alpha$-amide protons, due to Leu, Ala, Ser and Dab as well as a singlet.

Treatment of 1 with acetic anhydride in $\mathrm{MeOH}\left(0^{\circ} \mathrm{C}\right.$ for $\left.30 \mathrm{~min}\right)$ gave $N$-monoacetyl cirratiomycin A (3) and $N$-diacetyl cirratiomycin A (4), and re-acetylation of 3 under same condition gave 4 . In the ${ }^{1} \mathrm{H}-\mathrm{NMR}$ spectrum of $3\left(\mathrm{D}_{2} \mathrm{O}\right)$ the $\beta$-methine proton of Dab was observed at $4.4 \mathrm{ppm}$ which was shifted down-field from $4.0 \mathrm{ppm}$ of the parent antibiotic, indicating the $\beta$-amino group of Dab to be free. On the other hand, the ${ }^{1} \mathrm{H}-\mathrm{NMR}$ spectrum of 4 resembled very closely to that of 3 suggesting that the second acylation should occur at a free amino group attached to a quaternary carbon. In agreement with this, a new singlet amide proton appeared in the spectrum of 4 in DMSO- $d_{6}$, together with the doublet of $\beta$-amide proton of Dab. Treatment of 1 with dansyl chloride (DNS-Cl) at $\mathrm{pH} 9.5$ only dansylated the $\beta$-amino group of Dab but not the other one.

Mild acid hydrolysis of $1\left(6 \mathrm{~N} \mathrm{HCl}, 37^{\circ} \mathrm{C}, 7\right.$ days) and subsequent purification by column chromatography using Toyopearl HW $40 \mathrm{~F}$ and Dowex $50 \mathrm{~W}-\mathrm{X} 2$ (pyridine-AcOH buffer, $\mathrm{pH}$ 6.4) afforded four peptide fragments (5 8) containing $\mathrm{X}$ or $\mathrm{Y}$ in intact form. The $\mathrm{N}$-terminal residues of these fragments were determined by DNS method.

$\begin{array}{cc}\text { HMSer-Ala } & \mathbf{5} \\ \text { Dab-X-Leu } & \mathbf{6} \\ \text { Leu-Y } & \mathbf{7} \\ \text { Leu-Y-Ser } & \mathbf{8}\end{array}$

Dansylated 5 could not be obtained due probably to steric hindrance around the amino group of HMSer. This result indicated that the $\alpha$-amino group of Ala was acylated in this dipeptide. Isolation of these peptide fragments together with the fact that the $\alpha$-amino group of Dab was protected in the parent antibiotic, established the amino acid sequence of 1 as

\section{HMSer-Ala-Dab-X-Leu-Y-Ser}

In addition to these fragments, Dab was isolated without any racemization and identified to take an L-erythro configuration by ORD and 'H-NMR specta. ${ }^{1)}$ The FD mass of 6 exhibited $(\mathrm{M}+\mathrm{Na})^{+}$ion peaks at $M / z 342$ and 364 , respectively, indicating the molecular weight of 341 , and further spectral data allowed to assign the molecular formula of $\mathrm{X}$ as<smiles>O=C(O)C1CCCNNC1</smiles>

9<smiles>CCC(C)=C(N)C(=O)O</smiles> 


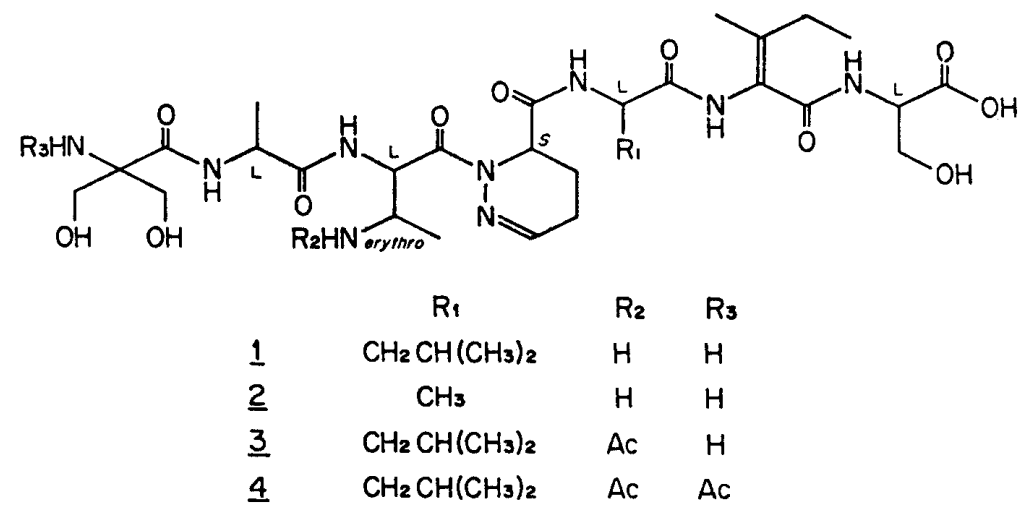

Fig. 1. The Structures of Cirratiomycin A, B and Derivatives.

$\mathrm{C}_{5} \mathrm{H}_{8} \mathrm{~N}_{2} \mathrm{O}_{2}$. Catalytic hydrogenation of 6 over $\mathrm{PtO}_{2}$ in $1 \mathrm{~N} \mathrm{AcOH}$ (room temperature, 5 days) followed by hydrolysis gave Leu, Dab and L-ornithine which was identified by TLC, amino acid analysis and ORD. This result and the ${ }^{1} \mathrm{H}-\mathrm{NMR}$ spectrum of 6 showing the partial structure $-\mathrm{CH}-\mathrm{CH}_{2}-\mathrm{CH}_{2}-\mathrm{CH}=$ for $\mathrm{X}$, proved the unknown amino acid to be 2,3,4,5-tetrahydropyridazine-3-carboxylic acid (THPC) 9. Thus, the structure of 6 was elucidated as L-erythro Dab-(S)-THPC-L-Leu.

The EI mass spectrum of $N$-acetyl derivative of $7(\mathrm{~m} / z 284)$ suggested the molecular formula of $\mathrm{C}_{6} \mathrm{H}_{11} \mathrm{NO}_{2}$ for $\mathrm{Y}$ and the ${ }^{1} \mathrm{H}-\mathrm{NMR}$ spectral analysis of 7 revealed the structure of $\mathrm{Y}$ as 2,3-didehydroisoleucine ( $\triangle \mathrm{Ile}, 10$ ). Hydrogenation of 8 over $\mathrm{PtO}_{2}$ in $1 \mathrm{~N} \mathrm{AcOH}$ (room temperature, 5 days) followed by acid hydrolysis gave Leu, Ser and Ile, confirming the above conclusion and the sequence of 8 as Leu- 4 lle-Ser.

Upon irradiation of an amide proton ( $9.31 \mathrm{ppm}$ singlet, assignable to the amide proton of $\Delta \mathrm{Ile}$ ) in the ${ }^{1} \mathrm{H}-\mathrm{NMR}$ spectrum (DMSO- $d_{6}$ ), NOE effect was observed in singlet methyl protons of $\Delta$ lle indicating its configuration to be $E$. These experimental results confirmed the linear structure for 1 having the $\mathrm{N}$-terminal of HMSer which could not be dancylated because of its presumable steric hindrance, and the total structure of cirratiomycin $\mathrm{A}$ has been determined as described in 1 .

Cirratiomycin B (2) has closely related properties with 1 and the ${ }^{1} \mathrm{H}-\mathrm{NMR}$ and ${ }^{13} \mathrm{C}-$ NMR spectra were essentially superimposable to 1 , except the presence of Ala moiety instead of Leu. Mild acid hydrolysis of 2 gave amino acid segments HMSer-Ala, Dab-X-Ala and Ala-Y-Ser, and comfirmed its steucture as shown in Fig. 1.

CirratiomycinA and B are active against a narrow range of Lactobacillus including $L$. casei and some strains of Streptococci and Mycobacterium but substantially inactive against filamentous fungi and yeasts. Detailed data will be published successively.

Reference

1) W.K. Hausmann, D.B. Borders and J.E. Lancaster, J. Antibiot., 22, 207 (1969).

2) T.T. Otani, and M. Winitz, Arch. Biochem. Biophys., 90, 254 (1960). 